\title{
INFLUENCE OF TEMPERATURE AND HUMIDITY ON PHOTOFADING OF CRYSTAL VIOLET ON POLYMER SUBSTRATES
}

\author{
By Tamako Toda ${ }^{* 1}$ and Mitsuhiko Hida ${ }^{* 2}$ \\ *1 Showa Women's Junior College, 1-7.57 Taishido, Setagaya-ku, \\ Tokyo, 154 \\ *2 Department of Industrial Chemistry, Faculty of Technology, Tokyo \\ Metropolitan University, 2-1-1 Fukazawa, Setagaya-ku, Tokyo, \\ 158
}

\begin{abstract}
The effects of humidity and oxygen on the photofading of Crystal Violet(CV) in nylon 6 film were studied in detail. Both moisture and oxygen were necessasy for the formation of Michler's Ketone. The effects of temperature and humidity on the photofading of $\mathrm{CV}$ in nylon 6 and polyester films were discussed in terms of kinetics. The fading rate was accelerated with rises in temperature and humidity for both films, and the rate was lower in polyester film than in nylon. The quantum yield in film decreased with the progress of decay, whereas it was almost unchanged in solution. The relationship between relative quantum yield $(\phi)$ in film and absorbance $(A)$ at $\lambda_{\max }$ was expressed by the equation, $\phi=\beta\left(A-a_{0}\right)^{\mathrm{m}}$. The parameter $m$ indicates the ease of decrease of the rate with the progress of decay. The influences of temperature and humidity on the value of $m$ were compared. The value of $m$ depends on the initial absorb. ance in some cases. At elevated temperatures $m$ has smaller value in almost all the cases.
\end{abstract}

\section{INTRODUCTION}

Photofading of dye can be affected by many factors such as photochemical characters of the reaction, aggregation of dye and various physical conditions of the surroundings. Recently the effects of humidity and temperature on the photofading of dye have attracted some interests from practical side. However, few investigation has been done from the fundamental stand point so far.

In our previous paper the effects of temperature, humidity and oxygen on the formation of the photoproducts of Crystal Violet (CV) in nylon 6 film were discussed ${ }^{13}$. Under wet condittions the fading of $\mathrm{CV}$ proceeded at elevated temperatures, even in the dark. yielding carbinol as the main product. The irradiation of visible light $(\lambda>500 \mathrm{~nm})$, corresponding to the first absorption band of $\mathrm{CV}$, accelerated the fading of $\mathrm{CV}$ in the film, especially at elevated temperatures in the presence of humid air.

Analysis using both the least square method and the principal component analysis method revealed that the photoproducts were leuco compound ( $\mathrm{CVH})$, leuco base ( $\mathrm{CVOH})$ and Michler's Ketone (MK). accompanied with the formattion of other products such as their demethylated compounds.

The present investigation was designed to elucidate the effects of temperature, humidity and oxygen on the photofading of $\mathrm{CV}$ in both nylon and polyester films in terms of the photoproducts and kinetics.

\section{EXPERIMENTAL}

\subsection{Materials}

Crystal Violet Chloride (C. I. Basic Violet 3), GR grade of Kanto Chemical Co., Ltd., was used as previously reported ${ }^{11}$.

Nylon 6 film was same as previously used ${ }^{1)}$. Poly (ethylene terephthalate) (PET) film drawn biaxially of $9 \mu$ thickness was supplied from Teijin Co., Ltd. PET film was used after being treated in water at $130^{\circ} \mathrm{C}$ under pressure for $1 \mathrm{~h}$.

Irradiation was carried out in air or sufficiently deoxidized nitrogen. The effect of oxygen in dry or wet air was also examined. The deoxidization of dry 
or wet atmosphere was accomplished by using a deoxidizing agent supplied from Mitsubishi Gas Chemical Co., Ltd.

\subsection{Dyeing}

Nylon 6 film was dyed at $80^{\circ} \mathrm{C}$ for $1 \mathrm{~h}$ at various dye concentrations in 500:1 liquor ratio, and PET film was dyed at $130{ }^{\circ} \mathrm{C}$ for $1 \mathrm{~h}$ under pressure at var ious dye concentrations in 200:1 liquor ratio. All dyed films were washed succesively with water and ethanol in order to remove excess dye on film surface and air-dried at room temperature.

\subsection{Irradiation}

The dyed film was exposed to visible light $(\lambda>$ $500 \mathrm{~nm}$ ) in a Pyrex cell under the conditions of controlled temperature and humidity as previously des. cribed $^{1)}$. The dry atmosphere was attained by introducing dry air into the degassed cell. The sufficient elimination of oxygen was attained by attaching the deoxidizing agent in a bag in the upper part of the degassed cell. The constant moisture content 10.935 $\mathrm{mol} / \mathrm{m}^{3}$ ) was obtained by sealing after exposing the cell including the dyed film to saturated $\mathrm{CaSO}_{4}$ aqueous solution $^{\text {') }}$

The irradiation was carried out using a super highpressure mercury lamp $500 \mathrm{~W}$ (USHIO USH $500 \mathrm{D}$ ). The course of fading was traced spectrometrically by a SHIMADZU UV210-A spectrophotometer.

\section{RESULTS AND DISCUSSION}

\subsection{Effects of humidity and oxygen on the photo- reaction of $\mathrm{CV}$ in a nylon 6 film}

After exposure to the light, the faded film was boiled with ethanol, and the extract in ethanol was measured spectrophotometrically. The absorption spectra between $280 \mathrm{~nm}$ and $400 \mathrm{~nm}$ of photofading products were analyzed using both the least square method" and the principal component analysis method $^{1.2)}$. The relative amounts of photofading pro ducts are summarized in Table 1.

In the presence of both moisture and oxygen, $\mathrm{CVOH}$ and $\mathrm{MK}$ were notably formed but $\mathrm{CVH}$ was not formed, whereas in the presence of dry oxygen $\mathrm{CVH}$ was formed, but $\mathrm{CVOH}$ and $\mathrm{MK}$ were not formed. These results show that both moisture and oxygen play important roles in the formation of $\mathrm{CVOH}$ and MK. Kuramoto and Kitao ${ }^{3)}$ proposed that MK was formed by direct oxidation by singlet oxygen. On the other hand, our results suggest another mechanism of the formation of $\mathrm{MK}$, because moisture is also neces. sary for its formation. Tentatively MK is assumed to be produced by photo electron transfer to give $\mathrm{CV}$ radical followed by addition of oxygen:

$$
\mathrm{CV} \rightarrow \mathrm{CV}^{*}, \mathrm{CV}^{*}+\mathrm{OH}^{-}\left(\text {from } \mathrm{H}_{2} \mathrm{O}\right) \rightarrow \mathrm{CV}^{*}+\mathrm{OH}^{*} \text {, }
$$$$
\text { and } \mathrm{CV}^{\cdot}+\mathrm{O}_{2} \rightarrow \mathrm{MK}
$$

However, more detailed investigation must be done to elucidate the mechanism of the formation of MK.

\subsection{Kinetics of photofading of $\mathrm{CV}$ in polymer subs. trates}

The concentrations $\left(\mathrm{C}_{\text {calc }}\right)$ of the unchanged dye was calculated using relative amount of dye shown in Table 1. Fig. 1 shows that this concentration $\left(\mathrm{C}_{\mathrm{cal}}\right)$ is proportional to the concentration $\left(\mathrm{C}_{\mathrm{obs}}\right)$ calculated directly using the absorbance of the dyed nylon film

Table 1 The Effects of Humidity and Oxygen on Photo fading products of $\mathrm{CV}$ in a Nylon 6 Film

\begin{tabular}{lrrrrr}
\hline \multicolumn{1}{c}{$\begin{array}{c}\text { Reaction } \\
\text { conditions }\end{array}$} & $\mathrm{CV}$ & $\mathrm{CVH}$ & CVOH & MK & Total \\
\hline $35^{\circ} \mathrm{C}$, dry air & 61 & 13 & 0 & 1 & 75 \\
$35^{\circ} \mathrm{C}$, dry air & & & & & \\
absence of oxygen & 47 & 21 & 0 & 3 & 71 \\
$35^{\circ} \mathrm{C}, 98 \%$ air & 25 & 0 & 16 & 12 & 53 \\
$35^{\circ} \mathrm{C} .98 \%$ RH & & & & & \\
absence of oxygen & 17 & 34 & 0 & 1 & 52 \\
\hline
\end{tabular}

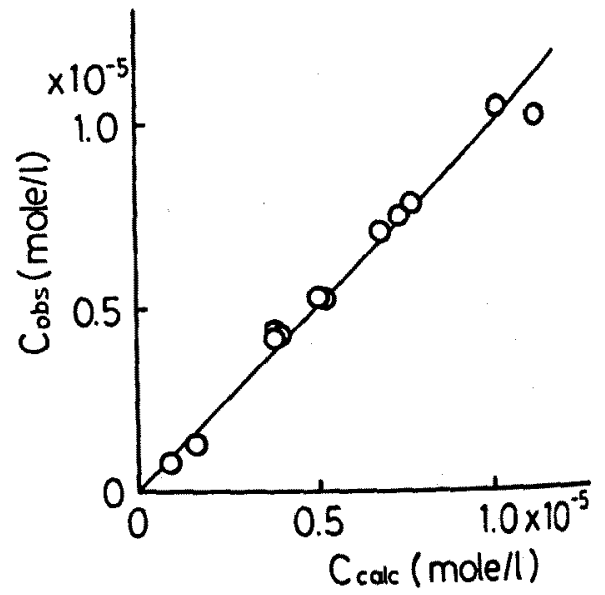

Fig. 1 Relationship between $C_{\text {obs }}$ and $C_{\text {calc }}$. $C_{\text {calc }}$ concentration of unchanged dye calculated using relative amount of CV obtained by the least square method " and $\mathrm{C}_{\mathrm{obs}}$, concentration of unchanged dye obtained directly from the absorbance of dyed film at $\lambda_{\max }$. 
at $\lambda_{\max }$ (corelation coefficient, 0.995 ). Consequently, the concentration of the unchaged dye determined by the absorbance of dyed film at $\lambda_{\max }$ was used throughout this work. The photofading curves of $\mathrm{CV}$ show that the fading rate is accelerated with rises in temperature and humidity in both nylon and PET films as illustrated in Fig. 2. The decay was slower in a PET film than in nylon.

\subsubsection{Relative quantum yield}

The fading rate of absorbance can be written by eq. 1, where the first term in the right-hand side corresponds to the rate of photofading and the second term to the rate of thermal reaction, since the absorbance of the film linearly decreased with time under the dark.

$$
-\mathrm{dA} / \mathrm{dt}=\phi \mathrm{V}+\mathrm{k}
$$

where $\mathrm{A}$ is the absorbance at $\lambda_{\max } \phi$ is quantum yield of the photofading, $\mathrm{V}$ is the rate of excitation of dye molecule and $\mathrm{k}$ is the zero order rate constant of thermal reaction.

The reaction conditions are abbreviated by temperature $\left(35,65\right.$ or $\left.89^{\circ} \mathrm{C}\right)$, relative humidity ( 0 or $98 \%$ $\mathrm{RH}$ ) and substrate (nylon (N) or PET (P)), such as $35 \mathrm{~N}(98)$ for nylon film in $98 \% \mathrm{RH}$ at $35^{\circ} \mathrm{C}$.

The rate constant $(k)$ of the thermal reaction was obtained by analysis of the thermal decay using linear regression. The results are compared in Table 2. The table shows that thermal reaction is rather slower than photoreaction, but can not be neglected under hot and/or wet conditions, and that the fitness of the zero order kinetics for thermal reaction is ex. cellent.

The thermal reaction in a PET film is much slower than in a nylon film as shown in Table 2. Although the thermal reaction was observed also in dry nylon film at higher temperature $(65 \mathrm{~N}(0)$ and $89 \mathrm{~N}(0))$, these thermal reactions are tentatively assumed to be reac. tion between water and the dye.

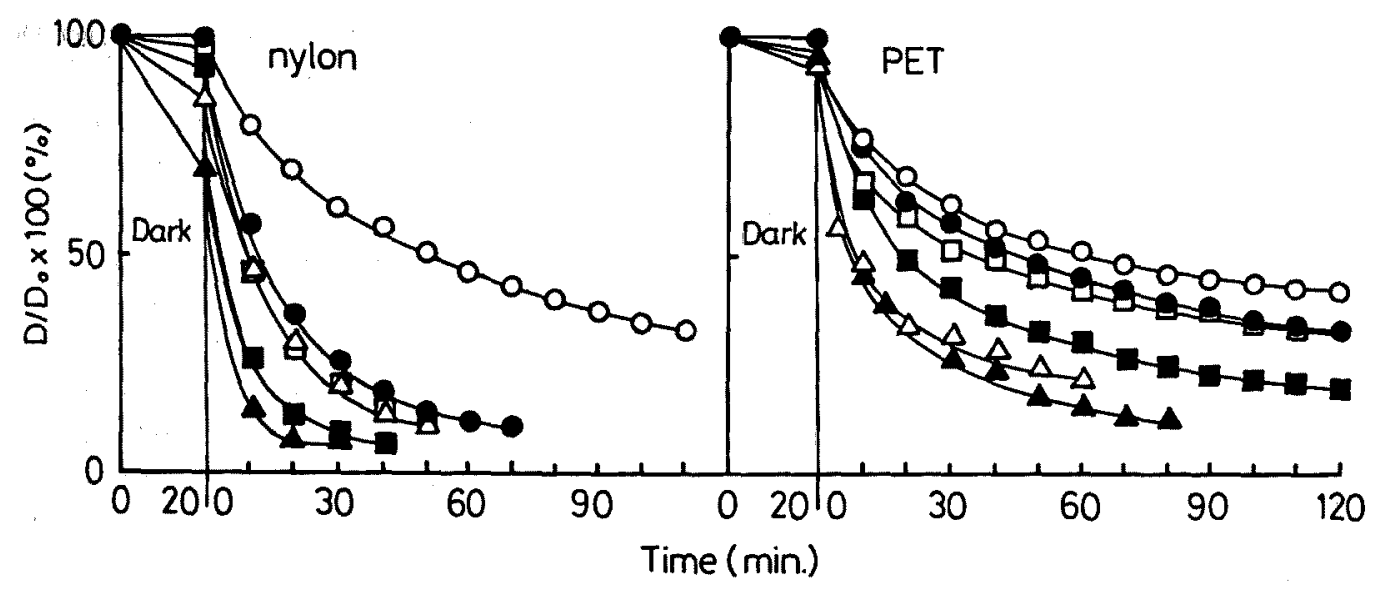

Fig. 2 Photofading curves of $\mathrm{CV}$ in nylon 6 and PET films under dry nitrogen at $35^{\circ} \mathrm{C}(\mathrm{O}), 65^{\circ} \mathrm{C}(\square)$, and $89^{\circ} \mathrm{C}(\Delta)$ or under $98 \% \mathrm{RH}$ in air at $35^{\circ} \mathrm{C}(\mathbf{O}), 65^{\circ} \mathrm{C}(\mathbf{\Delta})$, and $89^{\circ} \mathrm{C}(\boldsymbol{\Delta})$.

Table 2 The Effects of Temperature and Humidity on Rate Constant of Dark Reaction

\begin{tabular}{|c|c|c|c|c|c|}
\hline $\begin{array}{l}\text { Reaction } \\
\text { conditions }\end{array}$ & $89 \mathrm{~N}(98)$ & $89 \mathrm{~N}(0)$ & $65 \mathrm{~N}(98)$ & $65 \mathrm{~N}(0)$ & $89 \mathrm{P}(98)$ \\
\hline $\begin{array}{l}\mathrm{k} \times 10^{3} \mathrm{sec}^{-1} \\
\text { Correlation }\end{array}$ & 6.083 & 2.845 & 2.618 & 1.043 & 0.561 \\
\hline coefficient & -0.9995 & -0.9946 & -0.9938 & -0.9995 & -0.9825 \\
\hline Number of data & 13 & 13 & 13 & 15 & 9 \\
\hline
\end{tabular}


Quantum yield is calculated by eg. 2 derived from eq. 1.

$$
\phi=-(\mathrm{dA} / \mathrm{dt}+\mathrm{k}) / \mathrm{V}
$$

The rate of excitation of the dye is expressed by eq. 3 using some assumptions ${ }^{4) * 1}$

$$
V=V_{0}\left(1-\left(1-10^{-A}\right) / 2.303 \mathrm{~A}\right)
$$

where $V_{0}$ denotes a constant including strength of incident light per unit time and the band width of absorption spectrum, and $A$ is the value at the max. imum absorption. Combining eq. 2 with eq. 3 , relative quantum yield can be given by eq. 4 .

$$
\phi \mathrm{V}_{0}=-(\mathrm{dA} / \mathrm{dt}+\mathrm{k}) /\left(1-\left(1-10^{-\mathrm{A}}\right) / 2.303 \mathrm{~A}\right)
$$

Differential $(\mathrm{dA} / \mathrm{dt})$ was calculated from the decay curve of absorbance (A), which was approximated by a polynominals of the fourth order of time. The approximation fitted the decay curve excellently. The relative quantum yield $\left(\phi V_{0}\right)$ is simply written by $\phi$ hereinafter, since $V_{0}$ is constant under all reaction conditions.

In Fig. 3 the experimental fading curves are compared with the theoretical fading curves both in polymer and solution. The theoretical fading curves were calculated by assuming that $\phi$ was constant with the progress of decay. ${ }^{* 2}$. It is evident that the value of $\phi$ interestingly decreases with the progress of decay in a film, while it was almost unchanghd in solution.

Figs. 4 and 5 show the plots of the relative quantum yield $(\phi)$ in a film against absorbance $(A)$. The profiles of curves are concave upward or downward, thus $\phi$ is assumed to be approximated by eq. 5 .

$$
\phi=\beta\left(A-a_{0}\right)^{m}
$$

Value of a can be taken to be zero for almost all the cases except the case of the initial absorbance $\left(A_{0}\right)=$ 1.073 for $35 \mathrm{~N}(98)$. Parameter $m$ indicates the degree of change of $\phi$ with the progress of decay; when the value of $\mathrm{m}$ is large, the rate of decay is liable to slow down with the progress of reaction and vice versa. The parameter $\beta$ changes with the initial absorbance

* 1 The rate of excitation of dye can be expressed by eq. 3 , assuming that the strength of incident light linearly changes with wave length and the spectrum of the dye can be approximated by an isosceles triangle.

*2 The value of $\phi$ used in the calculation of the decay was determined by following equation

$$
\phi=(\mathrm{dA} / \mathrm{dt})_{0} /\left(1-\left(1-\mathrm{e}^{-2.303 \mathrm{~A}}\right) / 2.303 \mathrm{~A}_{0}\right)
$$

where $A_{0}$ denotes the initial absorbance.

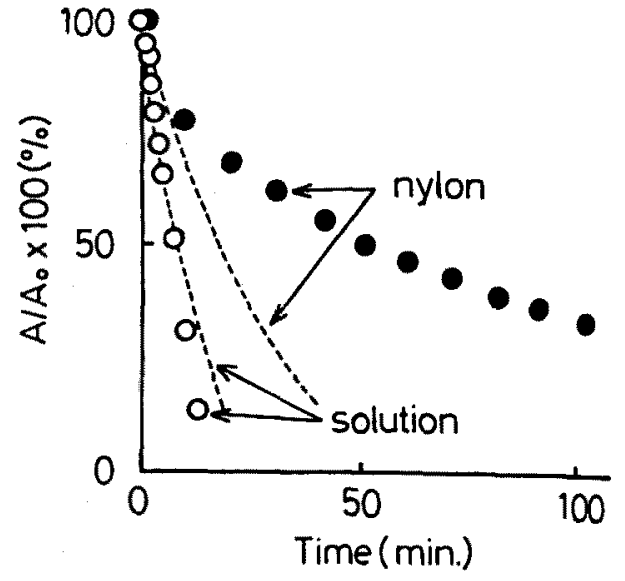

Fig. 3 Comparison of experimental and theoretical fad. ing curves of $\mathrm{CV}$ in a nylon 6 film and $\mathrm{CV}^{+}\left(\mathrm{CO}_{2} \mathrm{H}\right)$ $\left(\mathrm{CO}_{2}\right)^{-\prime}$ in degassed acetonitrile solution ${ }^{5}$. .......; calcula. tion by assuming $\phi=$ const.

$\left(A_{0}\right)$ under some reaction conditions. These values are summarized in Table 3 .

\subsubsection{Values of the parameters in a nylon film under dry conditions}

i) $35 \mathrm{~N}(0)$ : Plots of $\phi$ against A display the change of curvature as shown in Fig. 4 (a). Decrease of the reactivity is rather small at the early period, since the value of $\mathrm{m}$ is smaller than unity. However, $\mathrm{m}$ in creases to larger values with the progress of decay. The value of $m$ at the early period increases with in crease in the initial absorbance, while opposite tendency is observed at the later period. Although $m$ and $\beta$ change with the intial absorbance, plots of $\phi / \phi_{0}$ against $A / A_{0}$ are nearly independent of $A_{0}$ as illus. trated in Fig. 6.

ii) $65 \mathrm{~N}(0)$ : Both values of $\mathrm{m}$ and $\beta$ increase with increase in the initial absorbance. Since the value of $\mathrm{m}$ is smaller than that of $35 \mathrm{~N}(0)$, an elavated temper. ature results in suppression of decrease of the rate with the progress of reaction.

iii) $89 \mathrm{~N}(0)$ : The mean value of $\mathrm{m}(0.75 \pm 0.05)$. except the result at $\mathrm{A}_{0}=0.772$, indicates that the reactivity is similar to that of $35 \mathrm{~N}(0)$. The value of $\beta(0.1 \pm 0.02)$ is almost independent of $A_{0}$.

\subsubsection{Values of the parameters in a PET film under dry conditions}

The value of $m$ in a PET film is larger than that in a nylon film. Thus $\phi$ in PET more sensitively de- 


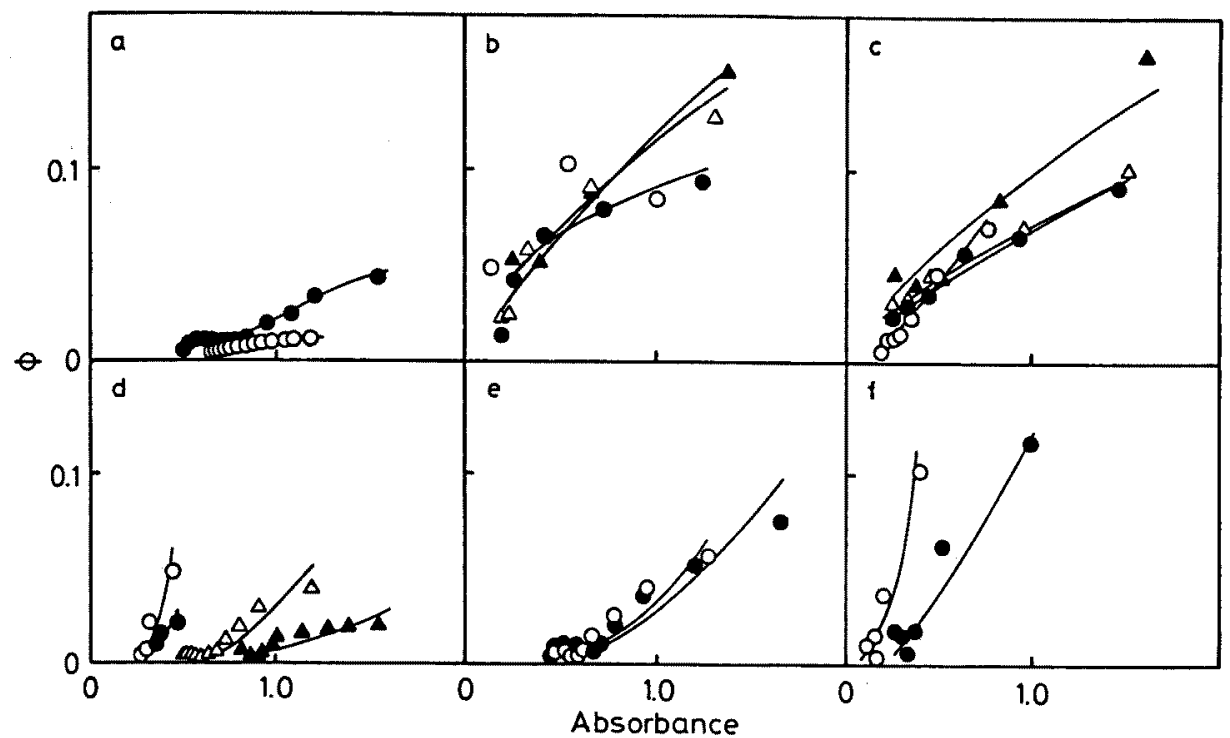

Fig. 4 Relationship between relative quantum yield and absorbance under dry conditions. a: $35 \mathrm{~N}(0)$ for $\mathrm{A}_{0}$, $1.179(\mathrm{O})$, and $1.536(\mathrm{O})$. b: $65 \mathrm{~N}(0)$ for $\mathrm{A}_{0}, 1.004(\mathrm{O}) ; 1.236(\mathrm{O}) ; 1.308(\Delta) ;$ and $1.371(\mathbf{A})$. c: $89 \mathrm{~N}$ (0) for $\mathrm{A}_{0}, 0.772(\mathrm{O}) ; 1.470(\mathrm{O}) ; 1.531(\Delta)$; and $1.626(\mathbf{\Delta})$. d: $35 \mathrm{P}(0)$ for $\mathrm{A}_{0}, 0.453(\mathrm{O}) ; 0.477(\mathbf{O})$; $1.191(\Delta)$; and $1.542(\Delta)$. e: $65 \mathrm{P}(0)$ for $\mathrm{A}_{0}, 1.308(\mathrm{O})$; and $1.704(\mathrm{O})$ f: $89 \mathrm{P}(0)$ for $\mathrm{A}_{0}, 0.398(\mathrm{O})$; and $0.998(0)$

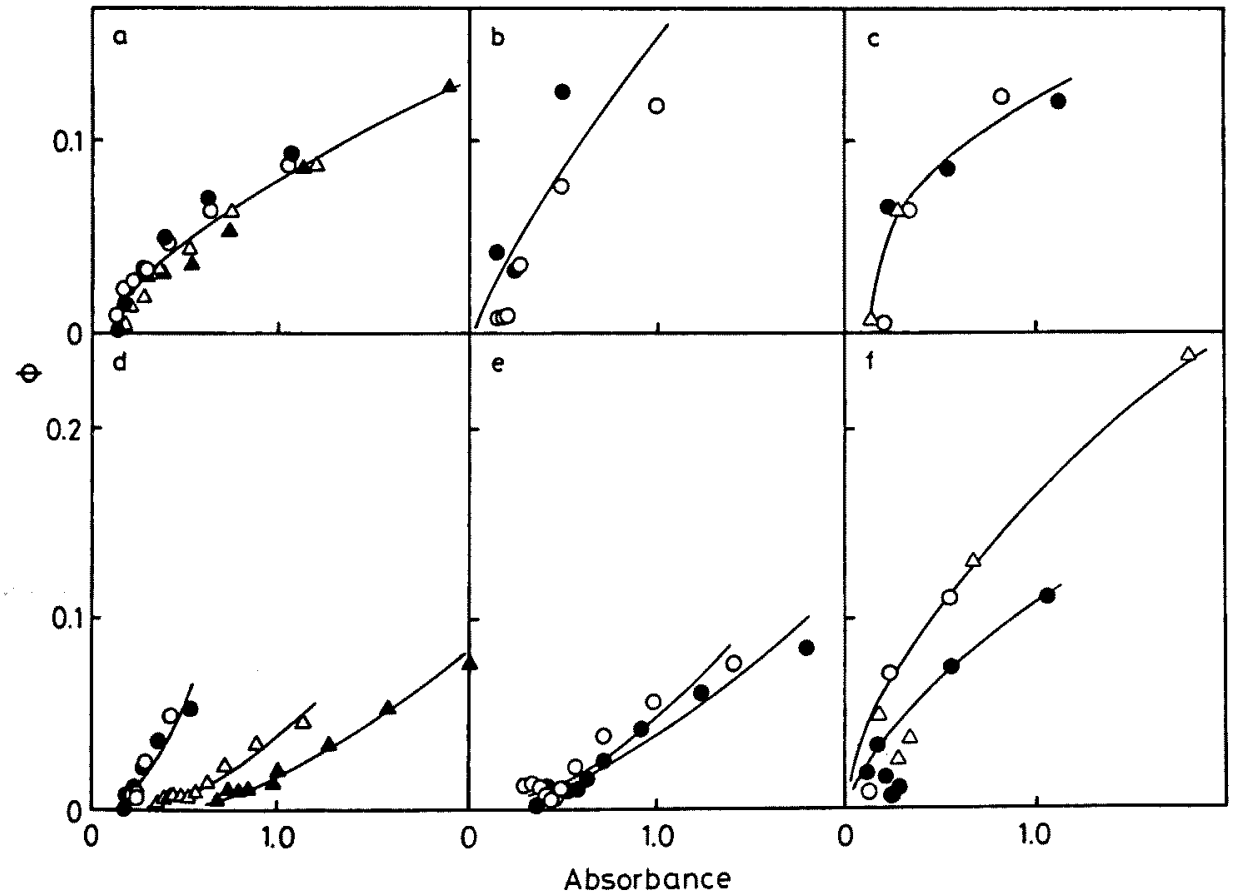

Fig. 5 Relationship between relative quantum yield and absorbance under wet conditions. a: $35 \mathrm{~N}(98)$ for $\mathrm{A}_{0}$, $1.046(O): 1.073(O) ; 1.200(\Delta)$ and $1.898(\Delta), b: 65 \mathrm{~N}(98)$ for $A_{0}, 1.002(O)$ and $1.672(\mathbf{O})$. c: $89 \mathrm{~N}$ (98) for $A_{0}, 0.833(\bigcirc) ; 1.132(O)$ and $1.140(\Delta)$ d: $35 \mathrm{P}(98)$ for $A_{0}, 0.427(O) ; 0.540(O) ; 1.142(\Delta)$ and $2.077(\Delta)$ e: $65 \mathrm{P}(98)$ for $A_{0}, 1.45(O)$ and $1.80(\bigcirc)$ f: $89 \mathrm{P}(98)$ for $A_{0 .} 0.539(O) ; 1.075(\bigcirc)$ and $1.843(\Delta)$. 
Table 3 Values of Parameters $m$ and $\beta$

\begin{tabular}{|c|c|c|c|c|}
\hline Conditions & $A_{0}$ & $\mathrm{~m}$ & $\ln \beta$ & $r$ \\
\hline \multirow[t]{4}{*}{$35 \mathrm{~N}(0)$} & 1.179 & 0.667 & -4.613 & 0.987 \\
\hline & & $(2.980)$ & $(-4.298)$ & $(0.993)^{* 1}$ \\
\hline & 1.536 & 1.429 & -3.721 & 0.999 \\
\hline & & (2.102) & $(-3.910)$ & $(0.992)^{* 1}$ \\
\hline \multirow[t]{4}{*}{$65 \mathrm{~N}(0)$} & 1.004 & 0 & -2.453 & - $* * * 1$ \\
\hline & 1.236 & 0.460 & -2.415 & 0.965 \\
\hline & 1.308 & 0.879 & -2.140 & 0.965 \\
\hline & 1.371 & 0.849 & -2.131 & 0.996 \\
\hline \multirow[t]{4}{*}{$89 \mathrm{~N}(0)$} & 0.772 & 1.515 & -2.191 & 0.980 \\
\hline & 1.470 & 0.769 & -2.690 & 0.999 \\
\hline & 1.531 & 0.671 & -2.641 & 0.985 \\
\hline & 1.626 & 0.730 & -2.332 & 0.924 \\
\hline \multirow[t]{4}{*}{$35 \mathrm{P}(0)$} & 0.453 & 4.986 & 1.077 & 0.937 \\
\hline & 0.477 & 3.611 & -0.965 & 0.985 \\
\hline & 1.191 & 3.173 & -3.558 & 0.960 \\
\hline & 1.542 & 4.845 & -5.072 & 0.895 \\
\hline \multirow[t]{2}{*}{$65 \mathrm{P}(0)$} & 1.308 & 2.817 & -3.423 & 0.843 \\
\hline & 1.704 & 1.601 & -3.305 & 0.997 \\
\hline \multirow[t]{2}{*}{$89 \mathrm{P}(0)$} & 0.398 & 1.991 & -0.437 & 0.988 \\
\hline & 0.998 & 1.550 & -2.106 & 0.931 \\
\hline \multirow[t]{4}{*}{$35 \mathrm{~N}(98)$} & 1.046 & 0.761 & -2.443 & 0.998 \\
\hline & 1.073 & 0.527 & -2.319 & $0.999^{* * 1}$ \\
\hline & 1.200 & 0.758 & -2.587 & 0.997 \\
\hline & 1.898 & 0.937 & -2.626 & 0.993 \\
\hline \multirow[t]{2}{*}{$65 \mathrm{~N}(98)$} & 1.002 & 1.461 & -1.863 & 0.952 \\
\hline & 1.672 & 1.054 & -1.651 & 0.953 \\
\hline \multirow[t]{3}{*}{$89 N(98)$} & 0.833 & & & \\
\hline & 1.132 & 0.469 & -2.123 & 0.960 \\
\hline & 1.140 & & & \\
\hline \multirow[t]{4}{*}{$35 \mathrm{P}(98)$} & 0.427 & & & \\
\hline & $0.540\}$ & 2.020 & -1.432 & 0.979 \\
\hline & 1.142 & 2.188 & -3.277 & 0.936 \\
\hline & 2.077 & 2.338 & -4.121 & 0.977 \\
\hline \multirow[t]{2}{*}{$65 \mathrm{P}(98)$} & 1.45 & 1.76 & -3.04 & $-* * *$ \\
\hline & 1.80 & 1.79 & -3.27 & 0.972 \\
\hline \multirow[t]{3}{*}{$89 \mathrm{P}(98)$} & 0.539 & 0.413 & -1.934 & $-* * *$ \\
\hline & 1.075 & 1.213 & -2.170 & $-\quad * * *)$ \\
\hline & 1.843 & 1.235 & -2.167 & $-\quad * * * j$ \\
\hline
\end{tabular}

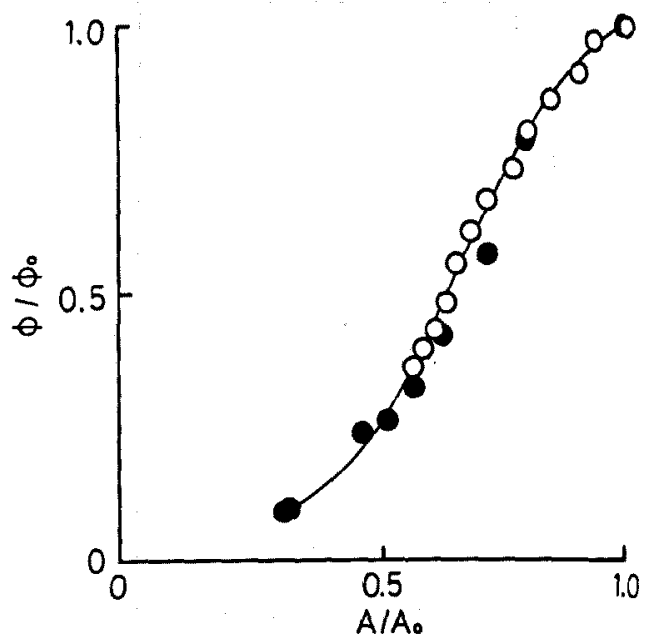

Fig. 6 Plots of $\phi / \phi_{0}$ versus $A / A_{0}$ in a nylon film under dry conditions at $35^{\circ} \mathrm{C} . \mathrm{A}_{0}: \bigcirc, 1.179$ and $\mathrm{O}, 1.536$.

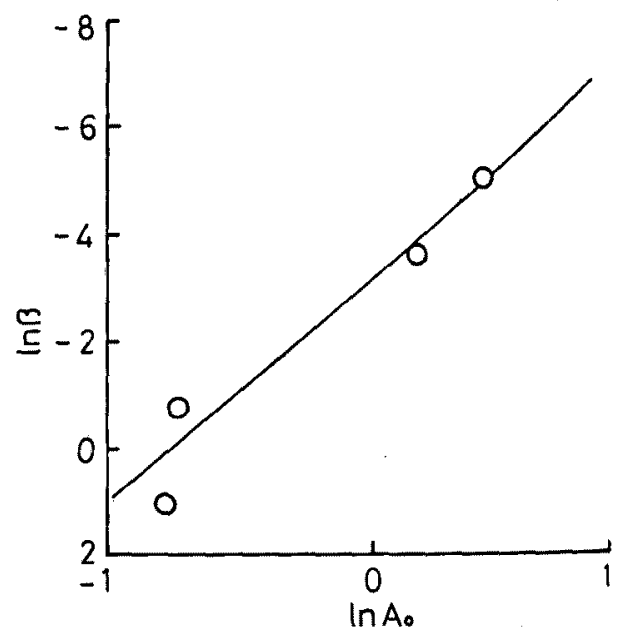

Fig. 7 Plots of $\ln \beta$ versus $\ln A_{0}$ in a PET film under dry conditions at $35^{\circ} \mathrm{C}$.

creases with the progress of decay than that in a nylon film.

i) $35 \mathrm{P}(0)$ : The value of $\mathrm{m}(4.15 \pm 1.43)$ is almost independent of $A_{0}$, but the value of $\beta$ decreases with increase in $A_{0}$ as shown in Fig. 7 (eq. 6).

$$
\begin{gathered}
\ln \beta=-(4.18 \pm 1.7) \ln A_{0}-(3.094 \pm 1.00) \\
(r=-0.96, n=4)
\end{gathered}
$$

Plots of $\phi$ against $A$ depend on $A_{0}$ as shown in Fig. 4 (d), but plots of $\phi / \phi_{0}$ against $A / A_{0}$ are almost independent of $A_{0}$ as shown in Fig. 8 (eq. 7 ).

$$
\begin{aligned}
\ln \left(\phi / \phi_{0}\right)= & (3.61 \pm 0.78) \ln \left(\mathrm{A} / \mathrm{A}_{0}\right) \\
& +(0.33 \pm 0.15)
\end{aligned}
$$


conditions of $35 \mathrm{P}(98)$ the value of $\mathrm{m}$ increases slightly with increase in $A_{0}$. The value of $\beta$ depends on $A_{0}$ (eq. 10).

$$
\begin{array}{r}
\ln \beta=-1.922 \ln A_{0}-2.807 \\
(r=-0.986, n=4)
\end{array}
$$

It is difficult to determine the definite values of $\mathrm{m}$ for the cases of $65 \mathrm{P}(98)$ and $89 \mathrm{P}(98)$ because of their large experimental errors. The values of $m$ were estimated as $0.413 \pm 0.766$ for $A_{0}(89 P(98))=0.539$, $1.213 \pm 0.653$ for $A_{0}(89 \mathrm{P}(98))=1.075$ and $1.235 \pm$ 0.551 for $A_{0}(89 P(98))=1.843$. However, it can be said that the value of $\mathrm{m}$ decreasees with increase in temperature.

\subsubsection{Dependency of the parameter $m$ on the irra- diation conditions}

As shown in Fig. 3, the rate of decay in polymer films slowed down with the progress of decay, contrary to the rate in solution. The parameter $\mathrm{m}$ in eq. 5 indicates the ease of decrease of the rate. Fig. 10 illustrates decay curves calculated by assuming the initial rate to be unity. Curvature of the decay curve depends on the value of $\mathrm{m}$. The larger the value of $\mathrm{m}$ is the more the rate of decay slows down with lap of irradiation time.

In Table 4 dependency of $m$ on the irradiation conditions is roughly compared. The value of $\mathrm{m}$ depends on $A_{0}$ in some cases. At the elevated temperature $m$ has smaller value in almost all the cases.

If the dye possesses the sole reactivity $(\phi), \mathrm{m}$ is vanished and the rate can not decrease with the pro. gress of decay. Hence the results suggest that a dis. tribution of reactivity may exist among the dye mole. cule in a film and it may be affected by temperature and humidity. Kinetic consideration on the parameter $(m)$ will be presented in a subsequent paper by assuming a distribution of reactivity in a film.

\section{ACKNOWLEDGMENTS}

We thank Mitsubishi Gas Chemical Co., Ltd. for deoxidizing agent, Unitika Co., Ltd. for nylon 6 film and Teijin Co., Ltd. for PET film.

\section{REFERENCES}

1) T. Toda and M. Hida, Sen-i Gakkaishi, 43,416 (1987)

2) K. Yamaoka and M. Takatsuki, Bull. Chem. Soc. Japan, 51, 3182 (1978)

3 ) N. Kuramoto and T. Kitao, Dyes and Pigments, 3 , 49 (1982)

4) M. Hida, M. Okabayashi, and A. Yabe, Kogyo Kagaku Zasshi, 72, 265 (1968); M. Hida and A. Yabe, Sen-i Gakkaishi, 36, T-85, (1980)

5) R. Nakamura and M. Hida, Sen-i Gakkaishi, 39 , $T-360(1983)$

\section{高分子基質上クリスタルバイオレットの光退色に対する温度，湿度の影響}

\section{昭和女子大学短期大学部 户田 玉子 東京都立大学工学部 飛田 㳦彦}

ナイロンフィルム中のクリスタルバイオレット(CV) の光退色におよばす湿度, 酸素の影響を詳細に検討し た。その結果, ミヒラーズケトン(MK)の生成には皮分 と酸素が共に必要であることが明らかとなった。さらに ナイロンおよびポリエステルフィルム(PET)中のCVの 光退色におよほす温度と湿度の影響を速度論的に解析し た。両フィルム中において染料の退色速度は温度, 湿度 の上昇とともに加速された。PETではナイロン中に比 ベ退色が荤い傾问となった。溶液中では CV の量子収率
にほとんど経時変化はないが，フィルム中の量子収率は 時間とともに減少し，減速効果が認められた。フィルム 中における相対量子收率 $(\phi) と \lambda_{\text {max }} に$ に忛る吸光度 (A)の関係を次式で示した。

$$
\phi=\beta\left(\mathrm{A}-\mathrm{a}_{0}\right)^{\mathrm{m}}
$$

式中のパラメーター $m$ は時間による减速のし易さを示 すものである。m值におよぼす温度、湿度の影籍を比㜞 検討した。 